\title{
Physical characterization of multiparticulate systems
}

\author{
Michele Georges Issa $^{1^{*}}$, Natalia Vieira de Souza ${ }^{1}$, Marcelo Dutra Duque ${ }^{1,2}$, Humberto Gomes Ferraz ${ }^{1}$ \\ ${ }^{1}$ Department of Pharmacy, Faculty of Pharmaceutical Sciences, University of São Paulo, \\ ${ }^{2}$ Department of Pharmaceutical Sciences, Institute of Environmental, Chemical and Pharmaceutical Sciences, \\ Universidade Federal de São Paulo - UNIFESP, Brazil
}

\begin{abstract}
The search for new pharmaceutical dosage forms and different drug delivery systems already used in therapeutics is a global trend, serving as an opportunity to expand the portfolio for the pharmaceutical industry. In this context, multiparticulate systems, such as pellets, granules, and minitablets, represent an attractive alternative, given the range of possibilities they provide. Among the methods used in the production of these systems, we highlight the process of extrusion-spheronization for pellet manufacture, wet granulation and hot-melt extrusion for the obtention of granules, and direct compression for minitablets. Although highly versatile, depending on the technology chosen, many processes and formulation variables can influence the ensuing stages of manufacture, as well as the final product. Therefore, the characterization of these small units is of fundamental importance for achieving batch homogeneity and optimal product performance. Analyses, including particle size distribution, morphology, density, porosity, mechanical strength and disintegration, are example tests used in this characterization. The objective of this review was to address the most widely used tests for the physical evaluation of multiparticulate systems.
\end{abstract}

Keywords: Multiparticulate systems/physical characterization. Pellets. Granules. Minitablets.

\section{INTRODUCTION}

An innovation can be considered a positive contribution when it is beneficial to society. Examples include promoting the dissemination of knowledge created or offering differentiated products and services that have added value (Araújo et al., 2010; Johnstone, Pairaudeau, Pettersson, 2011). In the pharmaceutical field, innovation can be exemplified by a technology that translates to direct benefit for patients, such as the introduction of new therapeutic arsenals providing alternatives to conventional treatments (Johnstone, Pairaudeau, Pettersson, 2011).

However, the entry of new chemical products onto the market is a slow and costly process, making the reformulation of already established drugs with wellknown effects an attractive option for the pharmaceutical industry (Issa et al., 2012a; Zerbini, Ferraz, 2011). Incorporation of drugs into new pharmaceutical dosage forms and different delivery systems have led to

\footnotetext{
*Correspondence: M. G. Issa. DEINFAR - Laboratório de Desenvolvimento e Inovação Farmacotécnica. Rua do Lago, 250, Prédio Semi-Industrial - Térreo, Cidade Universitária, Butantã, São Paulo, Brasil.E-mail: michelegeorges@usp.br
}

performance improvements in medications, resolving problems such as low absorption and lack of adherence to treatment, as well as providing business opportunities within existing portfolios that can be extended (Kulkarni et al., 2010; Sandner, Ziegelbauer, 2008).

Controlled-release, colonic release, pulsatile, oral disintegration and gastro-retentive systems are examples of alternatives that have been widely exploited. Among the pharmaceutical dosage forms, multiparticulates standout for the multitude of options they provide where, besides the above-mentioned systems, they can also be used in the production of immediate-release drugs and gastro-resistant systems (Cram, Bartlett, Heimlich, 2013; Dey, Majumdar, Rao, 2008; Greb, 2010; Zerbini, Ferraz, 2011).

Multiparticulates, whose size ranges from $0.05 \mathrm{~mm}$ to $5 \mathrm{~mm}$, are mainly used in the form of pellets, granules or minitablets that can be delivered in capsules or tablets (Dey, Majumdar, Rao, 2008; Greb, 2010; Pezzini, Silva, Ferraz, 2007; Zerbini, Ferraz, 2011). In these dosage forms, the drug dose is divided into smaller subunits, which, when administered disperse in the gastrointestinal tract. This provides numerous advantages over monolithic systems including only minor irritation of the mucosa, 
reduced variability in absorption and, in the case of controlled-release formulations, a lower risk of dose dumping (Cram, Bartlett, Heimlich, 2013; Dey, Majumdar, Rao, 2008; Santos et al., 2004).

Additionally, technological advantages include the obtention of different doses using the same formulation and the possibility of incorporation of incompatible drugs into a single medication (Pezzini, Silva, Ferraz, 2007; Zerbini, Ferraz, 2011). Given their small size, flexible doses and the possibility of obtaining oral disintegration systems, the use of particulates in formulations for pediatric and elderly patients has proven attractive (Cram, Bartlett, Heimlich, 2013; Dey, Majumdar, Rao, 2008; Grycze et al., 2011; Stoltenberg, Breitkreutz, 2011).

According to the type of system employed, different technologies may be used in the production of multiparticulates (Zerbini, Ferraz, 2011). In the case of pellets, extrusion-spheronization (Abdalla, Mader, 2007; Beringhs et al., 2012; Kulkarni et al., 2010) and coating inert core (Abdalla, Mader, 2007; Kulkarni et al., 2010) are the most commonly used processes. For the obtention of granules, wet granulation (Cai et al., 2013), melt granulation and hot-melt extrusion processes are used (Crowley et al., 2007; Gryczke et al., 2011; Mašic et al., 2012). In the case of minitablets, the granulation methods mentioned above and direct compression are used, where this process is carried out using a conventional machine equipped with multiple punches (Lopes et al., 2006; Zerbini, Ferraz, 2011).

Depending on the chosen technology, several variables (formulation, equipment, process) can influence the physical and physicochemical properties of the multiparticulates. These properties can impact coating, compression and the filling of gelatin capsules, as well as the behavior of the final product (Gómez-Carracedo et al., 2009; Mangwandi et al., 2012; Pund et al., 2010; Santos et al., 2002; Sonaglio et al., 2012).

Thus, the characterization of these systems is crucial to gaining a better understanding of the mechanisms that govern the release of the drug for further absorption and of aspects related to production.

Therefore, the objective of the present review was to address the most widely used tests and parameters for physical characterization of multiparticulate systems as a source of information for those who need to characterize these types of formulations.

\section{MULTIPARTICULATE DOSAGE FORMS AND DRUG DELIVERY SYSTEMS}

By using a variety of processes, different multiparticulate delivery systems can be produced resulting in a wide range of applications. Among these, the viability of drug association is important (Patel, Dhake, 2011).

Some example applications reported in the literature for pellets, granules and minitablets include:

\section{Pellets}

$\checkmark \quad$ Obtention of immediate-release systems, with a focus on masking drug flavor (Hamedelniel, Bajdik, Pintye-Hódi, 2010; Issa et al., 2012b; Patel, Patel, Patel, 2010);

$\checkmark \quad$ Controlled-release (Abbaspour, Sadeghi, Garekani, 2008; Bialleck, Rein, 2011; Cantor, Hoag, Augsburger, 2009a; Cantor, Hoag, Augsburger, 2009b; Franc et al., 2015; Ghanam, Kleinebudde, 2011; Ghosh, Chakraborty, 2013; Han et al., 2013; Heckötter et al., 2011; Hung et al., 2015; Pezzini, Ferraz, 2007; Ríos, Ghaly, 2015; Roblegg et al., 2011; Szkutnik-Fiedler et al., 2014; Wang et al., 2015; Xu, Liew, Heng, 2015; You et al., 2014);

$\checkmark \quad$ Improvement in dissolution of poorly soluble drugs (Abdalla, Mader, 2007; Abdalla, Klein, Mader, 2008; Chopra, Venkatesan, Betageri, 2013; Ibrahim, El-Badry, 2014; Lu et al., 2009; Patel et al., 2016); Gastro-retentive systems/ floating systems (Amrutkar, Chaudhari, Patil, 2012; Li et al., 2014; Pagariya, Patil, 2013; Qi et al., 2015; Zhang et al., 2012);

$\checkmark \quad$ Enteric release/gastro-resistant systems (AndreoFilho et al., 2009; Ghanam, Kleinebudde, 2011; Pund et al., 2010);

$\checkmark \quad$ Improvement of plant extract or active ingredient stability (Araújo-Junior et al., 2013; Beringhs et al., 2012; Burke et al., 2013);

$\checkmark$ Combination of different delivery systems (Bialleck, Rein, 2011; Liu et al., 2013);

High drug loading (Di Pretoro et al., 2010; Pund et al., 2010);

Colonic release (Di Pretoro et al., 2010; Ferrari et al., 2013; Omwancha et al., 2013; Rabiskova et al., 2012);

$\checkmark \quad$ Bio-adhesive formulation for vaginal application (Hiorth et al., 2013).

\section{Granules}

Controlled-release (Almeida et al., 2011; Grassi et al., 2003; Phaechamud, Thongpin, Choncheewa, 2012; Sharma, Amin, 2013; Tran et al., 2011; Verhoeven, Vervaet, Remon, 2006);

Gastro-retentive/floating systems (Malode, Paradkar, Devarajan, 2015); 
High drug loading in immediate-release systems (Cai et al., 2013);

Combination of different delivery systems (Dierickx et al., 2012; Dierickx, Remon, Vervaet, 2013);

Obtention of immediate-release systems, with a focus on masking drug flavor (Gryczke et al., 2011; Issa et al., 2012b);

$\checkmark \quad$ Improvement in dissolution of poorly soluble drugs (Deng et al., 2012; Kalidova, Fischbach, Kleinebudde, 2012);

$\checkmark \quad$ Enteric release/gastro-resistant systems (Del Gaudio et al., 2015);

$\checkmark$ Bio-adhesive system/increased gastric residence time (Pal et al., 2013);

\section{Minitablets}

Orally disintegrating/fast dissolving tablets (Stoltenberg, Breitkreutz, 2011);

$\checkmark \quad$ Controlled-release (Aleksovski et al., 2015; Lopes et al., 2006; Tomuta, Leucuta, 2007);

$\checkmark$ Combination of different delivery systems (Souza, Goebel, Andreazza, 2013);

$\checkmark \quad$ Colonic release (Vemula, 2015);

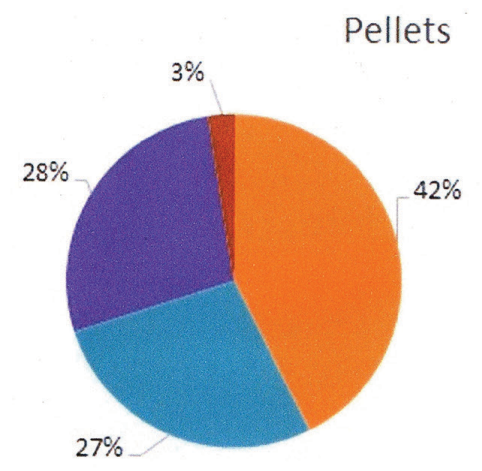

"Extrusion/spheronization/
coating

Extrusion/ spheronization

- Coating inert core

- Hot melt extrusion/ pelletization

Minitablets

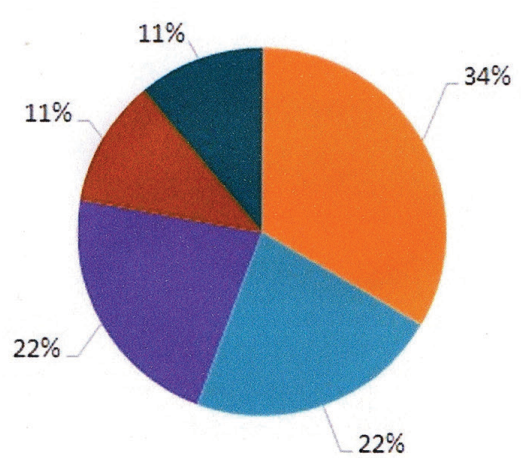

Ocular bio-adhesives (Bozdag et al., 2010; Weyenberg et al., 2003; Weyenberg et al., 2006);

Gastro-retentive/floating systems (Goole et al., 2008; Hauptstein et al., 2013; Katakam et al., 2014); Obtention of immediate-release systems, with a focus on masking drug flavor (Eckert, Pein, Breitkreutz, 2014);

Regarding the technologies employed in the obtention of these delivery systems (Figure 1) for pellets, extrusion followed by spheronization are the most exploited. For granules, the hot melt extrusion process is the most recently studied approach, whereas for the production of minitablets, direct compression is a widely used option.

Although multiparticulates provide many opportunities, their manufacture can involve a host of unit operations and variables. Additionally, they are inherently higher-cost processes because of their reliance on advanced technology. For example, obtaining pellets requires equipment such as extruders, a spheronizer and fluidized bed, whereas hot-melt extrusion requires screw extruders or co-extruders (Dey, Majumdar, Rao, 2008; Dierickx et al., 2012; Patel, Dhake, 2011; Zerbini, Ferraz, 2011).

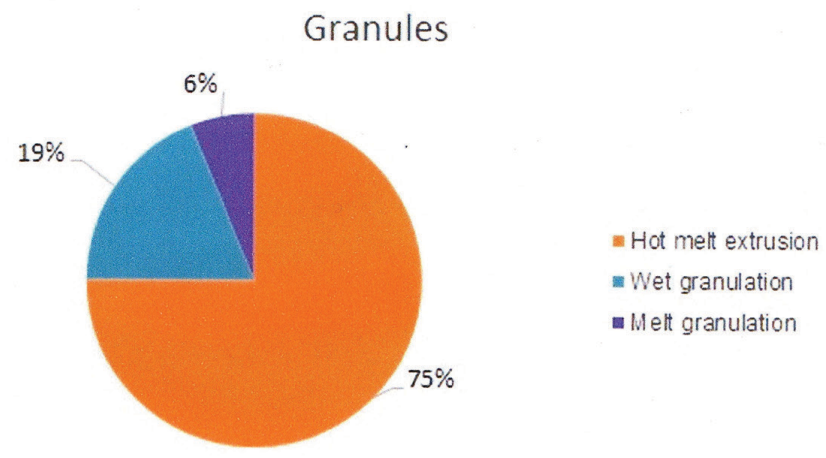
-Direct compression
mirect compression/ coating
mDry granulation/ compression
Dry granulation/ compression/
coating
Melt granulation/ compression
coating

FIGURE 1 - Technologies used in production of pellets, granules and minitablets. The information for charts was based on 65 articles on multiparticulate systems published in the 2003-2015 period and retrieved from the Science Direct and SciFinder databases. 
Nevertheless, assessment of the possibilities provided by these systems, such as the launch of new products and acceptance by patients, indicates that multiparticulate formulations are set to gain market space in the coming years (Greb, 2010).

\section{ASSAYS FOR PHYSICAL CHARACTERIZA- TION OF MULTIPARTICULATE SYSTEMS}

The goal of a system constituted by multiparticulate dosage forms is that their small functional units can release the drug in a reproducible way. Thus, the homogeneity of physical characteristics such as particle size, morphology, surface area, porosity and density, among others, is essential for the drug to perform as expected (Kulkarni et al., 2010; Mehta, 1989).

Besides the release effect, these properties may also exert an influence at some stages during processing, such as coating, compression and encapsulation (AlmeidaPrieto, Blanco-Mendez; Otero-Espinar, 2007; Santos et al., 2002; Sousa et al., 2002a).

Thus, together with tests evaluating a drug, suitable physical characterization of these small units must be performed at the product development stage, so that some properties are also considered in process control testing (Mehta, 1989). The knowledge generated and monitoring during production contribute to the reliability and yield of the batch, ultimately saving resources.

Pellets and granules are conventional systems studied for some time, while minitablets, melt granulation and hot melt extrusion are relatively new. The most common assays and parameters reported in the literature for physical characterization of multiparticulates are listed below. Some characterization tests are applied to all multiparticulate dosage forms, whereas others are specific to the process and or release system.

However, assays are commonly adapted according to the experience of the researchers and the results used to compare formulations. Further studies evaluating analytical variables of assays for multiparticulate systems are necessary.

\section{Particle size distribution}

Sieving is the most commonly employed method for particle size determination of particulate materials. Various sieve stirrers are available on the market whose movement can be mechanically induced, electromagnetic by airstream or ultrasonic pulses at different orientations. The meshes used, amount of material, equipment, as well as the intensity and duration of stirring, are key variables to be considered in this type of assay (European Pharmacopeia, 2008; Mehta, 1989; United States Pharmacopeia, 2015; Wan, 1994).

Mass used, sieves and stirring time are the parameters most commonly cited in the literature. In some cases, data relating to the intensity, frequency and amplitude are also described (Table I). However, assay conditions must be selected based on the configuration of the equipment and the material to be submitted to analyses. American and European pharmacopeia suggest determining the test endpoint as when there is no significant weight change between the sieves.

Although a very informative and accessible method, complementation with other assays such as microscopy (optical and electronic) can aid the interpretation of inconclusive results, since sieving is unable to detect variation in the particle shape (Mehta, 1989).

Apart from these techniques, particle size analyses by laser diffraction equipment is also cited in the literature for more accurate determination of average pellet diameter (Bialleck, Rein, 2011; Pund et al., 2010) and granules (Cai et al., 2013; Tissen et al., 2011).

As shown in Table I, the dry method is the most used technique for evaluating multiparticulate systems by laser diffraction (Ibrahim, El-Badry, 2014; Lin et al., 2011; Yeung, Rein, 2015). Using compressed air as the dispersing agent can be a better alternative than the wet method since liquid can partially dissolve the formulation, reducing the original size of the material.

\section{Morphology}

The quantity, type of drug and processing conditions, as well as the excipients used in the formulation, are factors that contribute to defining the morphology of multiparticulate materials. The shape of the linked units can significantly influence the physical and chemical properties of the dosage form (Almeida-Prieto, BlancoMendez, Otero-Espinar, 2007; Crowley et al., 2007; Gomez-Carracedo et al., 2009).

The particle size distribution based on sieving in combination with microscopic analyses techniques were originally used for morphological evaluation. Currently, analyses are based on geometric parameters calculated from the optical microscopic images derived (AlmeidaPrieto, Blanco-Mendez, Otero-Espinar, 2007; Mehta, 1989), including Feret diameters, circularity and aspect ratio (Figure 2). However, the result is highly dependent on the image analyses software used, as the same parameter can be calculated by different equations generating disparate results, thereby hindering the comparison of 
TABLE I - Example descriptions of parameters used for particle size distribution in multiparticulate systems

\begin{tabular}{|c|c|c|}
\hline Multiparticulate system & Assay conditions & Reference \\
\hline Granules & $\begin{array}{l}\text { Laser diffractometer, wet module, ethanol as dispersing agent, 10-12\% } \\
\text { obscuration and Franhoufer Theory }\end{array}$ & $\begin{array}{l}\text { Auriemma et al., 2013; Del } \\
\quad \text { Gaudio et al., } 2015\end{array}$ \\
\hline Granules & $\begin{array}{l}\text { Electromagnetic agitator sieves, } 5 \text { minutes of stirring and amplitude } \\
\text { of } 6.0 \mathrm{~mm}\end{array}$ & Cai et al., 2013 \\
\hline Granules & $\begin{array}{l}\text { Electromagnetic agitator sieves, } 700 \mathrm{~g} \text { of material, } 12 \text { minutes of } \\
\text { stirring, amplitude of } 0.7 \mathrm{~mm} \text { and range of } 8 \text { seconds }\end{array}$ & $\begin{array}{l}\text { Rahmanian, Naji, Ghadiri, } \\
2011\end{array}$ \\
\hline Granules (HME*) & Laser diffractometer, dry module and Franhoufer Theory & Yeung, Rein, 2015 \\
\hline Pellets & $\begin{array}{l}\text { Sonic sifter, } 5 \text { minutes of stirring, amplitude of } 6.0 \mathrm{~mm} \text { and pulse of } \\
5 \text { seconds }\end{array}$ & $\begin{array}{l}\text { Cantor, Hoag, Augsburger, } \\
\text { 2009a }\end{array}$ \\
\hline Pellets & $\begin{array}{l}\text { Electromagnetic agitator sieves, } 2 \text { minutes of stirring, } 50 \mathrm{~Hz} \text { frequency, } \\
\text { amplitude of } 2.0 \mathrm{~mm}\end{array}$ & Ferrari et al., 2013 \\
\hline Pellets & Mechanical sieve shaker and 5 minutes of stirring & Heckötter et al., 2011 \\
\hline Pellets & Laser diffractometer, dry method and $300 \mathrm{mg}$ of material & Ibrahim, El-Badry, 2014 \\
\hline Pellets & $\begin{array}{l}\text { Electromagnetic agitator sieves, } 2 \text { minutes of shaking, amplitude of } \\
1.0 \mathrm{~mm} \text { and range of } 10 \text { seconds }\end{array}$ & Issa et al., 2012b \\
\hline Pellets & Mechanical agitator sieves, $25 \mathrm{~g}$ of material and 15 minutes of agitation & Keen et al., 2015 \\
\hline Pellets & $\begin{array}{l}\text { Laser diffractometer, dry module, } 4-7 \% \text { of obscuration and } 60 \text { seconds } \\
\text { of measurement time }\end{array}$ & Lin et al., 2011 \\
\hline Pellets & $\begin{array}{l}\text { Electromagnetic agitator sieves, } 30 \mathrm{~g} \text { of material and } 5 \text { minutes of } \\
\text { agitation }\end{array}$ & Omwancha et al., 2013 \\
\hline Pellets & $\begin{array}{l}\text { Electromagnetic agitator sieves, } 5 \text { minutes of agitation, } 50 \mathrm{~Hz} \text { of } \\
\text { frequency, amplitude of } 1.0 \mathrm{~mm}\end{array}$ & Pund et al., 2010 \\
\hline Pellets & $\begin{array}{l}\text { Electromagnetic agitator sieves, } 50 \mathrm{~g} \text { of material, } 10 \text { minutes of } \\
\text { agitation and amplitude of } 1.0 \mathrm{~mm}\end{array}$ & Xu, Liew, Heng, 2015 \\
\hline
\end{tabular}

*Hot melt extrusion

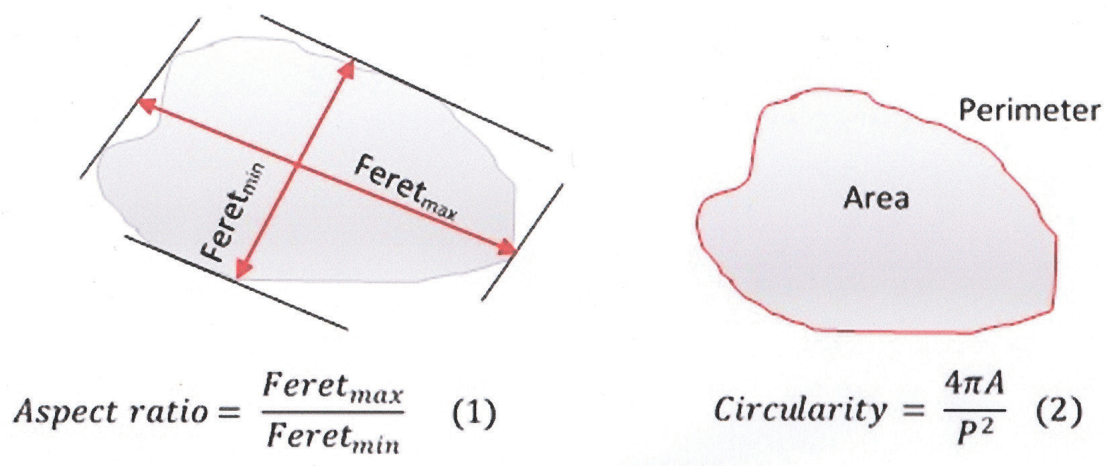

FIGURE 2 - Geometric parameters calculated in analyses of images of multiparticulate forms. Equations (1 and 2) are the most commonly employed - $\mathrm{A}$ = area and $\mathrm{P}=$ perimeter (Almeida-Prieto; Blanco-Mendez; Otero-Espinar, 2007).

data obtained by different laboratories (Almeida-Prieto, Blanco-Mendez,Otero-Espinar, 2007).

Another issue relates to a lack of standardization in terminology employed, where in some cases, different names can be assigned for the same parameter. For example, circularity that can also be denominated shape factor, sphericity index and surface factor, etc. (Almeida-
Prieto, Blanco-Mendez, Otero-Espinar, 2007; Mehta, 1989).

Table II shows examples in the literature of shape parameters calculated of multiparticulate systems.

In general, besides optical microscopy, screening electron microscopy (SEM) is also performed, where images from the former are used to calculate the shape 
TABLE II - Shape parameters calculated based on analyses of microscopic images in multiparticulate systems

\begin{tabular}{|c|c|c|}
\hline Multiparticulate system & Parameters calculated/Units evaluated/Image analysis program & Reference \\
\hline Granules & Sphericity/Image J & Auriemma et al., 2013 \\
\hline Granules & Sphericity and roughness/200/Image J & Del Gaudio et al., 2015 \\
\hline Granules $(\mathrm{MG})^{*}$ & $\begin{array}{l}\text { Feret diameter, aspect ratio, circularity and projection of sphericity/ } \\
\text { AnalySIS }^{\circledR}\end{array}$ & Mašić et al., 2012 \\
\hline Pellets & Circularity and radius ratio/50/Image-Pro ${ }^{\circledR}$ Plus 4.5.0.29 & Cespi et al., 2007 \\
\hline Pellets & $\begin{array}{l}\text { Aspect, average diameter, Feret diameter and sphericity/Image-Pro }{ }^{\circledR} \\
\text { Plus 4.5.0.29 }\end{array}$ & Andréo-Filho et al., 2009 \\
\hline Pellets & Circularity and Aspect ratio/Image $\mathrm{J}$ & $\begin{array}{l}\text { Chopra, Venkatesan, } \\
\text { Betageri, } 2013\end{array}$ \\
\hline Pellets & Sphericity and aspect ratio/Leco IA & Franc et al., 2015 \\
\hline Pellets & Aspect and circularity/Motic Images Advanced 3.2 & Ferrari et al., 2013 \\
\hline Pellets & $\begin{array}{l}\text { Feret diameter, average equivalent diameter, aspect ratio and } \\
\text { circularity/Leica Qwin }\end{array}$ & $\begin{array}{l}\text { Ghanam, Hassan, } \\
\text { Kleinebudde, } 2010\end{array}$ \\
\hline Pellets & Aspect ratio/200/Leica Quantimet 500 & $\begin{array}{l}\text { Hamedelniel, Bajdik, Pintye- } \\
\text { Hódi, } 2010\end{array}$ \\
\hline Pellets & Feret diameter and aspect ratio/Leica Qwin & Hiorth et al., 2013 \\
\hline Pellets & Average diameter, aspect and sphericity/Image-Pro ${ }^{\circledR}$ Plus 4.5.0.29 & Issa et al., 2012b \\
\hline Pellets & Feret diameter, aspect ratio and sphericity/300/AnalySIS ${ }^{\circledR}$ & Mehta et al., 2012 \\
\hline Pellets & Feret diameter, aspect ratio and sphericity/Windox 5.0 & Omwancha et al., 2013 \\
\hline Pellets & Aspect ratio, form factor and Feret diameter/100/Sonata Seescan & Podczeck, Newton, 2014 \\
\hline Pellets & Sphericity/200/Leco IA & Rabišková et al., 2012 \\
\hline Pellets & Feret diameter, aspect ratio and sphericity/Seescan Solitaire 512 & Santos et al., 2005 \\
\hline Pellets & Sphericity/50/Size Meter ${ }^{\circledR}$ & Sonaglio et al., 2012 \\
\hline Pellets & Sphericity/40/Seescan Solitaire 512 & Sousa et al., 2002a \\
\hline Minitablets & Feret diameter/ 300/ Leica QWin Lite v. 3.2 & $\begin{array}{l}\text { Czajkowska, Sznitowska, } \\
\text { Kleinebudde, } 2015\end{array}$ \\
\hline
\end{tabular}

*Melt granulation

parameters, while the latter is most commonly used for surface display of external and internal particles. Pellet and granule sizes can also be determined, however, this task is somewhat laborious, given the need for individual evaluation of various particles to extrapolate particle size distribution throughout the batch. It is possible, however, to evaluate the presence of agglomerates not detected in sieve analysis (Mehta, 1989).

For the analysis of SEM, samples should be prepared to facilitate the capture of signals and image building. Thus, samples are placed in an aluminum support containing a carbon tape and conductivity of the material is increased by depositing a thin layer of metallic ions such as gold, gold-palladium or platinum in an inert atmosphere of argon. Carbon deposition may also be used. The accelerating voltage, angle of inclination and working distance are example parameters that must be adjusted when carrying out this type of assay (Mehta, 1989). Descriptions found in the literature for conducting these analyses are given in Table III.

\section{Specific surface area}

Particle size, shape, porosity and roughness of particulate materials are factors influenced by the conditions employed in the core production step (pellets, granules and minitablets) and, according to the variation, can result in different surface areas (Mehta, 1989; Lowell et al., 2004). A high surface area usually requires additional amounts of coating and establishes better contact of the dosage form with gastrointestinal fluids, thus promoting the dissolution process (Lehmann, 1994; Mehta, 1989).

Among the techniques available for determination of specific surface area, gas adsorption is widely employed, 
Physical characterization of multiparticulate systems

TABLE III - Example descriptions of parameters used in SEM

\begin{tabular}{|c|c|c|}
\hline Multiparticulate system & Sample preparation/Assaying condition & Reference \\
\hline Granules & $\begin{array}{l}\text { Deposition of gold ions (thickness of coating 200-400 } \mathrm{A} \text { )/acceleration } \\
\text { voltage of } 20 \mathrm{keV}\end{array}$ & Auriemma et al., 2013 \\
\hline Granules & $\begin{array}{l}\text { Deposition of gold ions (thickness of coating 200-400 } \mathrm{A} \text { )/acceleration } \\
\text { voltage of } 20 \mathrm{keV}\end{array}$ & Del Gaudio et al., 2015 \\
\hline Granules (HME)* & Deposition of Platinum ions/increases of $60 \mathrm{x}$ and $70 \mathrm{x}$ & Dierickx et al., 2012 \\
\hline Granules (HME)* & $\begin{array}{l}\text { Carbon deposition/acceleration voltage of } 1-2 \mathrm{kV} \text {, working distance } \\
\text { of } 3 \text { and } 5 \mathrm{~mm} \text { at room temperature, and increases of } 500 \mathrm{x} \text { and } 5000 \mathrm{x}\end{array}$ & Dong et al., 2008 \\
\hline Granules & Deposition of gold-palladium ions/accelerating voltage of $10 \mathrm{kV}$ & Grassi et al., 2003 \\
\hline Granules (HME)* & $\begin{array}{l}\text { Deposition of chromium ions under vacuum/accelerating voltage } \\
\text { of } 5 \mathrm{kV}\end{array}$ & Jedinger et al., 2015 \\
\hline Granules (HME)* & $\begin{array}{l}\text { Carbon deposition } / 1 \mathrm{kV} \text { acceleration voltage and increases of } 150 \mathrm{x} \\
\text { and 2000x }\end{array}$ & Mašić et al., 2012 \\
\hline Pellets & $\begin{array}{l}\text { Deposition of gold-palladium ions in an inert atmosphere of argon/ } \\
\text { acceleration voltage of } 20 \mathrm{kV} \text { and increases of } 45 \mathrm{x} \text { to } 65 \mathrm{x}\end{array}$ & $\begin{array}{l}\text { Amrutkar, Chaudari, Patil, } \\
\qquad 2012\end{array}$ \\
\hline Pellets & $\begin{array}{l}\text { Deposition of gold ions/acceleration voltage of } 10 \mathrm{kV} \text { and increases } \\
\text { of } 60 \mathrm{x} \text { to } 300 \mathrm{x}\end{array}$ & Beringhs et al., 2012 \\
\hline Pellets & $\begin{array}{l}\text { Deposition of gold ions (thickness of coating of } 10 \mathrm{~nm} \text { )/acceleration } \\
\text { voltage of } 15 \mathrm{kV} \text { and increases of } 50 \mathrm{x} \text { to } 750 \mathrm{x}\end{array}$ & Burke et al., 2013 \\
\hline Pellets & $\begin{array}{l}\text { Deposition of gold ions (coating time }-2 \text { minutes)/acceleration } \\
\text { voltage of } 3 \mathrm{kV} \text { and increases of } 100 \mathrm{x} \text { and } 200 \mathrm{x}\end{array}$ & $\begin{array}{l}\text { Chopra, Venkatesan, } \\
\text { Betageri, } 2013\end{array}$ \\
\hline Pellets & Deposition of gold ions under vacuum/acceleration voltage of $10 \mathrm{kV}$ & Lu et al., 2009 \\
\hline Pellets & $\begin{array}{l}\text { Deposition of gold ions under vacuum (thickness of coating of } 6 \mathrm{~nm} \text { )/ } \\
\text { acceleration voltage of } 1.5 \mathrm{kV} \text { and working distance of } 10 \mathrm{~mm} \text { and } \\
\text { increases of } 500 \mathrm{x} \text { to } 2500 \mathrm{x}\end{array}$ & Marković et al., 2014 \\
\hline Pellets & $\begin{array}{l}\text { Deposition of carbon/acceleration voltage of } 10 \mathrm{kV} \text { and working } \\
\text { distance of } 7.5-7.8 \mathrm{~mm} \text { at room temperature, beam diameter of } 3 \text { and } \\
\text { increases of } 1000 \mathrm{x} \text { and } 5000 \mathrm{x}\end{array}$ & Omwancha et al., 2013 \\
\hline Pellets & $\begin{array}{l}\text { Deposition of gold-palladium ions under vacuum/acceleration voltage } \\
\text { of } 10 \mathrm{kV} \text { and increase of } 60 \mathrm{x}\end{array}$ & Pund et al., 2010 \\
\hline Pellets & Deposition of gold ions under vacuum/acceleration voltage of $20 \mathrm{kV}$ & Sabin et al., 2011 \\
\hline
\end{tabular}

*Hot melt extrusion

and the surface analysis methodology and porosity of solid materials by the BET equation are commonly used approaches (Lowell et al., 2004).

As this calculation takes into consideration the volume of gas adsorbed in the sample, different materials may be used as adsorbates. Nitrogen is the most commonly used adsorbate due to the properties of the molecules, which enable interaction with the surface of many materials, and because the gas is readily available in liquid state (Lowell et al., 2004). In relation to the parameters used in this technique, these often include, in addition to type of gas, the sample preparation time, corresponding to the removal of air from the surface of the material under vacuum and at the appropriate temperature, freezing and the number of points collected (multipoint or single point) to obtain the adsorptiondesorption isotherms.

As depicted in Table IV, the analysis is usually performed on a surface analyzer device using nitrogen gas due to its availability and low cost. The use of krypton was cited in some cases, probably due to its intrinsic characteristic of capturing small surface areas (Dong et al., 2008; Schrank et al., 2015; Sousa et al., 2002b).

Grassi et al. (2003) described surface area analysis performed using a mercury porosimeter, although this technique has the limitation of measuring closed pores (Giesche, 2006). 
TABLE IV - Examples descriptions of parameters employed in specific surface area analysis

\begin{tabular}{llc}
\hline Multiparticulate system & Assay conditions/ Equation & Reference \\
\hline Granules & $\begin{array}{l}\text { Degassing of samples for 72 hours at room temperature and under 50 } \\
\text { mTorr vacuum. Nitrogen adsorbate/multipoint BET }\end{array}$ & Chevalier et al., 2010 \\
Granules (HME)* & Krypton adsorbate and nitrogen/multipoint BET & Dong et al., 2008 \\
Granules (MG)** & $\begin{array}{l}\text { Mercury porosimeter }-0.75 \text { g sample and 30 minutes prior degassing/ } \\
\text { Rootare-Prenzlow }\end{array}$ & Grassi et al., 2003 \\
Pellets (HME)* & $\begin{array}{l}\text { Degassing of samples for 24 hours and freezing with liquid nitrogen } \\
\text { for 20 minutes. Nitrogen adsorbate/multipoint BET }\end{array}$ & Bialleck, Rein, 2011 \\
Pellets & $\begin{array}{l}\text { Degassing of samples for 24 hours under vacuum. Nitrogen adsorbate } \\
\text { Pellets }\end{array}$ & Santos et al., 2004 \\
& $\begin{array}{l}\text { Degassing of samples under vacuum and freezing in liquid nitrogen. } \\
\text { Pellets }\end{array}$ & Schrank et al., 2015 \\
& $\begin{array}{l}\text { Ditrogen or krypton adsorbate }- \text { pressure of 0.05 and 0.2 psi/ BET } \\
\text { Krypton or nitrogen adsorbate/multipoint BET and single point BET }\end{array}$ & Sousa et al., 2002b \\
\hline
\end{tabular}

*Hot-melt extrusion; $* *$ Melt granulation

\section{Density and flow behavior}

The knowledge of the density of a batch of multiparticulates is of great importance in the final stages of processing, such as in the mixture of different pellet formulations or granules, the coating step on a fluidized bed, and in capsule filling or tableting (Mehta, 1989; Santos et al., 2006).

Although the density calculation is fairly simple, obtained by dividing the mass of the material by the volume it occupies, there are several approaches for this parameter (Table V), all of which convey different information that can be used in any step of production or even in elucidating the release profile of the formulation (He, 2009; Santos et al., 2006).

True density is a characteristic of the material derived from its manufacturing process and related to particle size. In this case, the volume adopted for calculation takes into account only the solid material, discounting the volume occupied by internal or external pores and spaces between particles (He, 2009; Lowell et al., 2004; Santos et al., 2006).

Helium pycnometry is the preferred method for determining true density, given the small size of the gas molecule, which has greater ability to penetrate very small pores. If the porosity of the multiparticulate form is very low or it possesses pores which may be filled by mercury or another liquid in which the material does not disintegrate, mercury porosimetry or liquid displacement method may also be used (Lowell et al., 2004).

For apparent density, sometimes called effective density, the volume is considered the volume occupied by the solid material plus internal pores, which are inaccessible. In most cases, mercury porosimetry is the method of choice for determining apparent density (Lowell et al., 2004). With the true density and apparent density

TABLE V - Types of densities used in the evaluation of multiparticulate systems (Lowell et al., 2004; Santos et al., 2006)

\begin{tabular}{lll}
\hline Density & Definition & Method of determination \\
\hline True & Volume of material excluding pores (external/internal) & $\checkmark$ He pycnometry \\
& and space between particles & Hg porosimetry \\
& & Fluid displacement \\
\hline Apparent/ effective & $\begin{array}{l}\text { Volume of material excluding only external pores and } \\
\text { space between particles }\end{array}$ & $\checkmark$ Hg porosimetry \\
& Volume of material with pores (external/internal) and & $\checkmark$ Beaker \\
\hline Bulk & spaces between particles & Scott volumeter \\
\hline Tapped & Volume of material excluding spaces between particles & $\checkmark$ Voluminometer - compacted density \\
& & equipment \\
\hline
\end{tabular}


data, the percentage porosity of the multiparticulate form can be calculated (Ghanam, Hassan, Kleinebudde, 2010; Santos et al., 2005), as outlined below.

Bulk and compacted density provide information on the space occupied by the formulation and may be used, for example, to define batch sizes and equipment used in production and selection of capsule size. Furthermore, these parameters can indicate the flow of material when the compressibility index and Hausner ratio are calculated (He, 2009; Mehta, 1989; United States Pharmacopeia, 2015).

As shown in Table VI, density is a frequently studied property in multiparticulate systems.
Angle of repose and flow rate are also extensively used to evaluate the rheology of multiparticulate formulations. Several methods are available although, in most cases, these properties are determined as described in U.S. Pharmacopeia, i.e. by using a hopper in which the material passes and forms a cone, whereby the inclination angle is calculated (United States Pharmacopeia, 2015).

The flow of a material is dependent on several factors, such as humidity and the degree of particle consolidation, and hence the result may vary according to the conditions used for analyses. Thus, different devices have emerged for determining flow more accurately, which are based on the use of shear forces on the quantity

TABLE VI - Densities evaluated in multiparticulate systems

\begin{tabular}{|c|c|c|}
\hline Multiparticulate system & Properties evaluated & Reference \\
\hline Granules & Flow & Cai et al., 2013 \\
\hline Granules & Bulk, tapped and true densities & Chevalier et al., 2010 \\
\hline Granules (HME)* & True density & $\begin{array}{l}\text { Dong et al., 2008; Yeung, } \\
\text { Rein, } 2015\end{array}$ \\
\hline Granules & Bulk and tapped densities; Hausner ratio & $\begin{array}{l}\text { Eckert, Pein; Breitkreutz, } \\
\qquad 2014\end{array}$ \\
\hline Granules (HME)* & Bulk and tapped densities; compressibility index & Grycze et al., 2011 \\
\hline Granules & Bulk and tapped densities; compressibility index and angle of repose & Roohulaah et al., 2014 \\
\hline Granules & Bulk and tapped densities & Issa et al., 2012a \\
\hline Granules & $\begin{array}{l}\text { Bulk and tapped densities, compressibility index, Hausner ratio, angle } \\
\text { of repose and flow rate }\end{array}$ & Lamolha, Serra, 2007 \\
\hline Granules $(\mathrm{MG}) * *$ & Bulk and tapped densities and compressibility index & Mašić et al., 2012 \\
\hline Granules $(\mathrm{MG})^{* *}$ & Bulk and tapped densities, angle of repose and compressibility index & Tran et al., 2011 \\
\hline Pellets & Bulk and tapped densities, angle of repose and Hausner ratio & $\begin{array}{l}\text { Amrutkar, Chaudari, Patil, } \\
\qquad 2012\end{array}$ \\
\hline Pellets & Bulk and tapped densities, Hausner ratio and compressibility index & Beringhs et al., 2012 \\
\hline Pellets & $\begin{array}{l}\text { Bulk and tapped densities, angle of repose, Hausner ratio and } \\
\text { compressibility index }\end{array}$ & $\begin{array}{c}\text { Chopra, Venkatesan, } \\
\text { Betageri, 2013; Franc et al., } \\
\text { 2015; Pagariya, Patil, } 2013\end{array}$ \\
\hline Pellets & Bulk and apparent densities & Costa, Pais, Sousa, 2004 \\
\hline Pellets & Bulk, tapped and apparent densities & $\begin{array}{l}\text { Ghanam, Hassan, } \\
\text { Kleinebudde, } 2010\end{array}$ \\
\hline Pellets & True density & $\begin{array}{l}\text { Grassi et al., 2003; Hiorth et } \\
\text { al., 2013; Issa et al., 2012b }\end{array}$ \\
\hline Pellets & Bulk and tapped densities, compressibility index and angle of repose & Peng et al., 2015 \\
\hline Pellets & $\begin{array}{l}\text { Bulk, tapped and true densities, compressibility index, angle of repose } \\
\text { and Hausner ratio }\end{array}$ & Rabišková et al., 2012 \\
\hline Pellets & True and effective densities & Santos et al., 2005 \\
\hline Pellets & Bulk and tapped densities & Sonaglio et al., 2012 \\
\hline Minitablets & True density & Lopes et al., 2006 \\
\hline
\end{tabular}

*Hot-melt extrusion. **Melt granulation 
of sample and application time, as well as the interactions between the particles of the material and the cell used for analysis (Amidon, Secreast, Mudie, 2009).

\section{Porosity}

Porosity is a property that relates to the release of drug from the dosage form, directly influencing the steps of disintegration and dissolution. High material porosity can lead to low density particles improving the dissolution process (D'Arcy, Persoons, 2011). It is determined by processing conditions and formulation, especially in the case of pellets and granules, due to the volume of liquid used in kneading and removal in the drying step (Farber, Tardos, Michaels, 2003; Mehta, 1989; Pund et al., 2010).

The size and distribution of pores can facilitate the penetration of gastrointestinal fluid in multiparticulate systems but these are not the only parameters. Another important issue associated with the surface of these units is the composition of the formulation, which can affect their wettability (Riippi et al., 1998). Furthermore, the presence of pores on the surface of the cores may influence coating quality, and hence lead to variation in the performance of the product (Mehta, 1989; Santos et al., 2006).
Techniques for determining the porosity of multiparticulate systems reported in the literature include porosimetry by mercury intrusion, determination of density by helium pycnometer or deposition of solid material, gas adsorption, scanning electron microscopy and X-ray computed tomography (XCT) (Table VII). The most used of these techniques are mercury porosimetry and helium pycnometer. Mercury porosimetry, can provide results such as pore size and its distribution volume and percentage porosity of the material, as illustrated using the densities in Equation 3 (Ghanam, Hassan, Kleinebudde, 2010; Mehta et al., 2012; Santos et al., 2005).

$$
\varepsilon=1-\frac{\rho_{a}}{\rho_{h}}
$$

(Equation 3)

$\varepsilon=$ porosity, $\rho_{a}=$ effective/apparent density, $\rho_{h}=$ true density

Since porosimetry is dependent on the pressure applied and mercury contact angle with the surface of the sample, there is a limitation for the evaluation of materials having pores of very small size (below $1.5 \mathrm{~nm}$ ). In these cases, nitrogen adsorption technique using the BET equation may provide better results (Lowell et al., 2004; Santos et al., 2006).

TABLE VII - Example methods used to determine the porosity of multiparticulate systems

\begin{tabular}{|c|c|c|}
\hline Multiparticulate system & Method/parameters calculated & Reference \\
\hline Granules (HME)* & X-ray tomography/porosity and equivalent pore diameter & Almeida et al., 2011 \\
\hline Granules & Coating density analyzer/porosity & Ansari, Stepanek, 2008 \\
\hline Granules & $\mathrm{Hg}$ porosimeter/porosity & Chevalier et al., 2010 \\
\hline Granules & $\mathrm{Hg}$ porosimeter and coating density analyzer/porosity & Rahmanian et al., 2009 \\
\hline Granules (HME)* & He pycnometer/porosity & $\begin{array}{l}\text { Verhoeven, Vervaet, Remon, } \\
2006\end{array}$ \\
\hline Pellets (HME)* & He pycnometer and Hg porosimeter/relative density & Bialleck, Rein, 2011 \\
\hline Pellets & He pycnometer/porosity & $\begin{array}{l}\text { Cespi et al., 2007; Pund et } \\
\text { al., 2010; Rabišková et al., } \\
\text { 2012; Santos et al., } 2002\end{array}$ \\
\hline Pellets & He pycnometer and $\mathrm{Hg}$ porosimeter/porosity and average pore radius & $\begin{array}{l}\text { Ghanam, Hassan, } \\
\text { Kleinebudde, } 2010\end{array}$ \\
\hline Pellets & $\begin{array}{l}\mathrm{Hg} \text { porosimeter/pore volume distribution, average pore diameter } \\
\text { and porosity }\end{array}$ & Nordström et al., 2013 \\
\hline Pellets & Fluid displacement method/porosity & Patel et al., 2016 \\
\hline Pellets & He pycnometer and $\mathrm{Hg}$ porosimeter/porosity & Santos et al., 2004 \\
\hline Pellets & $\begin{array}{l}\text { He pycnometer and } \mathrm{Hg} \text { porosimeter/porosity, total pore volume, total } \\
\text { pore area and average pore diameter }\end{array}$ & Santos et al., 2005 \\
\hline Pellets & $\mathrm{Hg}$ porosimeter/average pore diameter & Sonaglio et al., 2012 \\
\hline Minitablets & He pycnometer/porosity & Weyenberg et al., 2003 \\
\hline
\end{tabular}

*Hot melt extrusion 
SEM and XCT are options for viewing the pore distribution in the multiparticulates. SEM is intended for only qualitative determination while $\mathrm{XCT}$ also provides quantification of pore size and porosity (Farber, Tardos, Michaels, 2003; Mehta, 1989).

\section{Mechanical strength}

The various unit operations to which the multiparticulate forms are subjected require a certain mechanical strength of these small units, particularly when steps such as fluidized bed coating and compression are involved. Advantageous from an economic standpoint as a way of reducing production costs, incorporation into tablet is a strategy adopted. However, it is important that the drug release properties are maintained after compression, for example, the coating film integrity (Cespi et al., 2007; Santos et al., 2004; Santos et al., 2006).

As can be seen in Table VIII, mechanical strength is constantly evaluated in multiparticulate forms. In the case of minitablets, the most common tests already used in tablets, such as hardness and friability, are employed (Lopes et al., 2006; Tomuta, Leucuta, 2007; Weyenberg et al., 2006). For granules and pellets, tensile strength (Equation 4) and Young's elastic modulus, related to the stiffness and crushing strength (hardness) of the material, are the most frequently determined. For this purpose, a strain chart can be obtained by using a texture analyzer device, in which the material is exposed to a given load against time (Santos et al., 2006; Šibanc et al., 2013; Yeung, Rein, 2015).

$$
\delta=\frac{0.4 F}{\pi r^{2}}
$$

$\delta=$ tensile strength; $F=$ intensity of the force required to break; $r^{2}=$ radius of the particle obtained by Feret's diameter

For friability, different adjustments are performed (Table IX), typically using glass or steel balls, in order to increase the material's abrasion and improve the sensitivity of the method (Chopra, Venkatesan, Betageri, 2013; Issa et al., 2012b; Santos et al., 2006). A friabilometer is the equipment used in most cases, where sometimes a stirring system is used instead (Chevalier et al., 2010; Stoltenberg, Breitkreutz, 2011). Alternatively, the approach used by Li et al. (2014) can be adopted, in which the material is subjected to drastic conditions in the coating equipment.

The result is obtained by determination of the percentage mass of the material lost when exposed to abrasion, requiring the use of a sieve to separate the fraction formed as powder which is weighed during the assay. The study of Issa et al. (2012b) reported an alternative in which the mass loss is measured by comparing the amounts retained in the sieves, where the particle size distribution is carried out before and after the assay.

TABLE VIII - Strength properties evaluated in multiparticulate systems

\begin{tabular}{|c|c|c|}
\hline Multiparticulate system & Parameters calculated & Reference \\
\hline Granules & Tensile strength & Cai et al., 2013 \\
\hline Granules & Hardness & Chevalier et al., 2010 \\
\hline Granules (HME)* & Tensile strength & Yeung, Rein, 2015 \\
\hline Pellets & Elastic limit and elastic modulus & Abbaspour, Sadeghi, Garekani, 2008 \\
\hline Pellets & Tensile strength & $\begin{array}{l}\text { Bialleck, Rein, 2011; Podczeck, Newton, } \\
\text { 2014; Santos et al., } 2005\end{array}$ \\
\hline Pellets & Hardness, tensile strength and relaxation module & Cespi et al., 2007 \\
\hline Pellets & Hardness & $\begin{array}{l}\text { Costa, Pais, Sousa, 2004; Ghanam, } \\
\text { Hassan, Kleinebudde, 2010; Hamedelniel, } \\
\text { Bajdik, Pintye-Hódi, 2010; Rabišková et } \\
\text { al., 2012; Rahmaniam, Naji, Ghadiri, } 2011\end{array}$ \\
\hline Pellets & Tensile strength and elastic modulus & Šibanc et al., 2013 \\
\hline Minitablets & Hardness & $\begin{array}{c}\text { Aleksovski et al., 2015; Lopes et al., } \\
\text { 2006; Stoltenberg, Breitkreutz, 2011; } \\
\text { Tomuta, Leucuta, 2007; Weyenberg et al., } \\
2006\end{array}$ \\
\hline Minitablets & Tensile strength & Tissen et al., 2011 \\
\hline
\end{tabular}

*Hot melt extrusion 
TABLE IX - Conditions employed for determination of the friability of multiparticulate systems

\begin{tabular}{|c|c|c|}
\hline Multiparticulate system & Conditions employed & Reference \\
\hline Granules & $\begin{array}{l}10 \mathrm{~g} \text { of material in a glass container subjected to } 240 \text { oscillations for } \\
4 \mathrm{~min} .\end{array}$ & Chevalier et al., 2010 \\
\hline Granules & $10 \mathrm{~g}$ of material, 200 spheres of $4 \mathrm{~mm}$, at $25 \mathrm{rpm}$ for $10 \mathrm{~min}$. & Mehta et al., 2012 \\
\hline Pellets & $10 \mathrm{~g}$ of material, 10 spheres of $5 \mathrm{~mm}$, at $25 \mathrm{rpm}$ for $10 \mathrm{~min}$. & Adbdalla, Mäder, 2007 \\
\hline Pellets & $10 \mathrm{~g}$ of material, at $200 \mathrm{rpm}$ & $\begin{array}{l}\text { Amrutkar, Chaudari, Patil, } \\
2012\end{array}$ \\
\hline Pellets & $6 \mathrm{~g}$ of material, $25 \mathrm{spheres}$ of $2 \mathrm{~mm}$, at $25 \mathrm{rpm}$ for $4 \mathrm{~min}$. & $\begin{array}{l}\text { Chopra, } \\
\text { Venkatesan,Betageri, } 2013\end{array}$ \\
\hline Pellets & $10 \mathrm{~g}$ of material, 200 spheres of $4.3 \mathrm{~mm}$, at $25 \mathrm{rpm}$ for $4 \mathrm{~min}$. & Issa et al., 2012b \\
\hline Pellets & $\begin{array}{l}5 \mathrm{~g} \text { of material, atomization pressure of } 0.2 \mathrm{bar} \text {, air flow of } 45 \mathrm{~Hz} \text { for } \\
20 \mathrm{~min} .\end{array}$ & Li et al., 2014 \\
\hline Pellets & $6 \mathrm{~g}$ of material, 25 spheres of $2 \mathrm{~mm}$, at $100 \mathrm{rpm}$ & Pund et al., 2010 \\
\hline Minitablets & $1 \mathrm{~g}$ of material in a glass container, at $25 \mathrm{rpm}$ for $4 \mathrm{~min}$. & $\begin{array}{l}\text { Eckert, Pein, Breitkreutz, } \\
2014\end{array}$ \\
\hline Minitablets & $1 \mathrm{~g}$ of material, 20 spheres of $5 \mathrm{~mm}$, at $25 \mathrm{rpm}$ for $4 \mathrm{~min}$. & $\begin{array}{l}\text { Gaber, Nafee, Abdallah, } \\
2015\end{array}$ \\
\hline Minitablets & $10 \mathrm{~g}$ of material, at $100 \mathrm{rpm}$ & Katakam et al., 2014 \\
\hline Minitablets & 20 units, at $25 \mathrm{rpm}$ for $4 \mathrm{~min}$. & Lopes et al., 2006 \\
\hline Minitablets & $\begin{array}{l}1 \mathrm{~g} \text { of material in a glass container subjected to agitation in a shaker } \\
\text { and } 200 \text { vibrations per minute for } 1 \text { hour }\end{array}$ & $\begin{array}{l}\text { Stoltenberg, Breitkreutz, } \\
2011\end{array}$ \\
\hline Minitablets & 10 units, 100 spheres of $4 \mathrm{~mm}$, at $25 \mathrm{rpm}$ for $10 \mathrm{~min}$. & Weyenberg et al., 2006 \\
\hline
\end{tabular}

\section{Disintegration}

Given the tendency of the incorporation of multiparticulate systems in the form of tablets, for example, in the case of a multiple unit pellet system (MUPS), disintegration should occur quickly so that each unit can operate independently. Thus, this step in the release process becomes a key feature and can improve the selection of excipients to be used in the formulation, as well as the conditions employed in compression (Abbaspour, Sadegni, Garekani, 2008; Ghanam, Kleinebudde, 2011; Mehta et al., 2012).

For immediate release multiparticulate systems, the disintegration process of each subunit is vital because this step occurs prior to the dissolution process. The occurrence of disintegration problems can affect drug release and consequently drug absorption (Mahato, 2007).

When in tablet form, the assay method is the conventional one, evaluating six units using the apparatus described in the pharmacopoeias (Abbaspour, Sadeghi, Garekani, 2008; Chopra, Venkatesan, Betageri, 2013; Mehta et al., 2012). However, assays with small units are also described in the literature and, therefore, adjustments can be made either by using narrower mesh to ensure that the material is stirred and/or by employing downsized sample holders (Abdalla, Mader, 2007; Ghanam, Kleinebudde, 2011), as well as other devices, such as the roller bottle equipment used by Ghosh and Chakraborty (2013).

\section{CONCLUSION}

The fact that pharmaceutical dosage forms can be delivered in small functional unities, makes multiparticulates an attractive option for the development of new formulations. On the other hand, given the small size of these units, physical characterization tests become fundamental to understand the process variables and to assist the formulator in the selection of excipients and parameters used in the various unit operations involved in production. Tests are now well known. However, as multiparticulates are relatively new compared to traditional tablets, some adjustments are needed to improve the sensitivity of the techniques used. Adequate physical characterization is achieved by combining different assays. The most used tests are granulometric distribution by the sieving method, morphology by determining shape parameters based on microscopy images derived, surface 
area analysis by the gas adsorption technique, density and porosity by combining pycnometry and porosimetry techniques, as well as mechanical strength, especially for obtaining breakdown tension, hardness, friability and disintegration.

\section{ACKNOWLEDGEMENTS}

The authors would like to thank the Coordenação de Aperfeiçoamento de Pessoal de Nível Superior (CAPES/ Brazil).

\section{REFERENCES}

Abbaspour MR, Sadeghi F, Garekani HA. Design and study of ibuprofen disintegrating sustained-release tablets comprising coated pellets. Eur J Pharm Biopharm. 2008;68(3):747-759.

Abdalla A, Mäder K. Preparation and characterization of a self-emulsifying pellet formulation. Eur J Pharm Biopharm. 2007;66(2):220-226.

Abdalla A, Klein S, Mäder K. A new self-emulsifying drug delivery system (SEDDS) for poorly soluble drugs: characterization, dissolution, in vitro digestion and incorporation into solid pellets. Eur J Pharm Sci. 2008;35(5):457-464.

Aleksovski A, Luštrik M, Šibanc R, Dreu R. Design and evaluation of a specific, bi-phase extended release system based on differently coated mini-tablets. Eur J Pharm Sci. 2015;75:114-122.

Almeida A, Possemiers S, Boone MN, De Beer T, Quinten T, Van Hoorebeke L, Remon JP, Vervaet C. Ethylene vinyl acetate as matrix for oral sustained release dosage forms produced via hot-melt extrusion. Eur J Pharm Biopharm. 2011;77(2):297-305.

Almeida-Prieto S, Blanco-Méndez J, Otero-Espinar FJ. Microscopic image analysis techniques for the morphological characterization of pharmaceutical particles: Influence of the software, and the factor algorithms used in the shape factor estimation. Eur J Pharm Biopharm. 2007;67(3):766-776.

Amidon GE, Secreast PJ, Mudie D. Particle, powder and compact characterization In: Yihong Q, Chen Y, Zhang GZZ, Liu L, Porter W, editors. Developing solid oral dosage forms: pharmaceutical theory and practice. 1st ed. Burlington: Elsevier; 2009. p. 163-186.
Amrutkar PP, Chaudhari PD, Patil SB. Design and in vitro evaluation of multiparticulate floating drug delivery system of zolpidem tartarate. Colloid Surf B. 2012;89:182-187.

Andréo-Filho N, Pessole L, Issa MG, Villela C, Ferraz HG. Gastro-resistant pellets of didanosine obtained by extrusion and spheronization: assessing the production process. Lat Am J Pharm. 2009;28(1):32-40.

Ansari MA, Stepanek F. The effect of granule microstructure on dissolution rate. Powder Tecnol. 2008;181(2):104-114.

Araújo EF, Barbosa CM, Queiroga ES, Alves SS. Propriedade intelectual: proteção e gestão estratégica do conhecimento. Rev Bras Zootecn. 2010;39(suppl Esp):1-10.

Araújo-Junior CA, Costa FSO, Taveira SF, Marreto RN, Valadares MC, Lima EM. Preparation of pellets containing Pothomorphe umbellata extracts by extrusion-spheronization: improvement of 4-nerolidylcatechol photostability. Rev Bras Farmacogn. 2013;23(1):169-174.

Auriemma G, Mencherini T, Russo P, Stigliani M, Aquino RP, Del Gaudio P. Prilling for the development of multi-particulate colon drug delivery systems: Pectin vs. pectin-alginate beads. Carbohyd Polym. 2013;92(1):367-373.

Beringhs AO, Souza FM, Campos AM, Ferraz HG, Sonaglio D. Technological development of extract pellets by extrusionspheronization. Rev Bras Farmacogn. 2012;23(1):160-168.

Bialleck S, Rein H. Preparation of starch-based pellets by hotmelt extrusion. Eur J Pharm Biopharm. 2011;79(2):440-448.

Bozdag S, Weyenberg W, Adriaens E, Dhondt MMM, Vergote $\mathrm{V}$, Vervaet $\mathrm{C}$, et al. In vitro evaluation of gentamicin- and vancomycin-containing minitablets as a replacement for fortified eye drops. Drug Dev Ind Pharm. 2010;36(11):1259-1270.

Burke MD, He X, Cook C, Petrov GA, Long S, Coffin MD. Stability enhancement of drug layered pellets in a fixed dose combination tablet. AAPS PharmSci. 2013;14(1):312-320.

Cai L, Farber L, Zhang D, Li F, Farabaugh J. A new methodology for high drug loading wet granulation formulation. Int J Pharm. 2013;441(1-2):790-800.

Cantor SL, Hoag SW, Augsburger LL. Formulation and characterization of a compacted multiparticulate system for modified release of water-soluble drugs - Part I acetaminophen. Drug Dev Ind Pharm. 2009a;35(3):337-351. 
Cantor SL, Hoag SW, Augsburger LL. Formulation and characterization of a compacted multiparticulate system for modified release of water-soluble drugs - Part II theophylline and cimetidine. Drug Dev Ind Pharm. 2009b;35(5):568-582.

Cespi M, Bonacucina G, Misici-Falzi M, Golzi R, Boltri L, Palmieri GF. Stress relaxation test for the characterization of the viscosity of pellets. Eur J Pharm Biopharm. 2007;67(2):476-484.

Chevalier E, Viana M, Cazalbou S, Makein L, Dubois J, Chulia D. Ibuprofen-loaded calcium phosphate granules: Combination of innovative characterization methods to relate mechanical strength to drug location. Acta Biomaterialia. 2010;6(1):266274.

Chopra S, Venkatesan N, Betageri GV. Formulation of lipid bearing pellets as a delivery system for poorly soluble drugs. Int J Pharm. 2013;446(1-2):136-144.

Costa FO, Pais AACC, Sousa JJS. Analysis of formulation effects in the dissolution of ibuprofen pellets. Int J Pharm. 2004;270(1-2):9-19.

Cram A, Bartlett JA, Heimlich J. Oral multiparticulate as a flexible solid dosage form approach for paediatric use. Biopharma Asia. 2013;Jun:1-14.

Crowley MM, Zhang F, Repka MA, Thumma S, Upadhye SB, Battu SK, et al. Pharmaceutical applications of Hot-Melt Extrusion: Part I. Drug Dev Ind Pharm. 2007;33(9):909-926.

Czajkowska M, Sznitowska M, Kleinebudde P. Determination of coating thickness of minitablets and pellets by dynamic image analysis. Int J Pharm. 2015;495(1):347-353.

D’Arcy DM, Persoons TJ. Mechanistic modelling and mechanistic monitoring: simulation and shadowgraph imaging of particulate dissolution in the flow-through apparatus. J Pharm Sci. 2011;100(3):1102-1115.

Del Gaudio P, De Cicco F, Sansone F, Aquino RP, Adami R, Ricci M, et al. Alginate beads as a carrier for omeprazole/ SBA-15 inclusion compound: A step towards the development of personalized paediatric dosage forms. Carbohyd Polym. 2015;133:464-472.

Deng W, Majumdar S, Singh A, Shah S, Mohammed NN, Jo $\mathrm{S}$, et al. Stabilization of fenofibrate in low molecular weight hydroxypropylcellulose matrices produced by hot-melt extrusion. Drug Dev Ind Pharm. 2012;39(2):290-298.
Dey NS, Majumdar S, Rao MEB. Multiparticulate drug delivery systems for controlled release. Trop J Pharm Res. 2008;7(3):1067-1075.

Dierickx L, Saerens L, Almeida A, De Beer, T, Remon JP, Vervaet $\mathrm{C}$. Co-extrusion as manufacturing technique for fixeddose combination mini-matrices. Eur J Pharm Biopharm. 2012;81(3):683-689.

Dierickx L, Remon JP, Vervaet C. Co-extrusion as manufacturing technique for multilayer mini-matrices with dual drug release. Eur J Pharm Biopharm. 2013;85(3):1157-1163.

Di Pretoro G, Zema L, Gazzaniga A, Rough SL, Wilson DI. Extrusion-spheronisation of highly loaded 5-ASA multiparticulate dosage forms. Int J Pharm. 2010;402(1-2):153164.

Dong Z, Chatterji A, Sandhu H, Choi DS, Chokshi H, Shah N. Evaluation of solid state properties of solid dispersions prepared by hot-melt extrusion and solvent co-precipitation. Int J Pharm. 2008;355(1-2):141-149.

Eckert C, Pein M, Breitkreutz J. Lean production of taste improved lipidic sodium benzoate formulations. Eur J Pharm Biopharm. 2014;88(2):455-461.

European Pharmacopeia 6st ed. Strasbourg: Council of Europe, 2008. p. 325-331.

Farber L, Tardos G, Michaels JN. Use of X-ray tomography to study the porosity and morphology of granules. Powder Technol. 2003;132(1):57-63.

Ferrari PC, Souza FM, Giorgetti L, Oliveira GF, Ferraz HG, Chaud MV, et al. Development and in vitro evaluation of coated pellets containing chitosan to potential colonic drug delivery. Carbohyd Polym. 2013;91(1):244-252.

Franc A, Muselík J, Sabadková D, Neumann D. Preparation of pellets with controlled release of glucose as prevention of hypoglycaemia in paediatric patients. Eur J Pharm Sci. 2015;75:72-80.

Gaber DM, Nafee N, Abdallah OY. Mini-tablets versus pellets as promising multiparticulate modified release delivery systems for highly soluble drugs. Int J Pharm. 2015;488(1-2):86-94.

Ghanam D, Hassan I, Kleinebudde P. Compression behavior of k-carrageenan pellets. Int J Pharm. 2010;390(2):117-127. 
Ghanam D, Kleinebudde P. Suitability of k-carrageenan pellets for the formulation of multiparticulate tablets with modified release. Int J Pharm. 2011;409(1-2):9-18.

Ghosh A, Chakraborty P. Formulation and mathematical optimization of controlled release calcium alginate micro pellets of frusemide. BioMed Res Int. 2013;Article ID 819674:1-14.

Giesche H. Mercury porosimetry: a general (practical) overview. Part Part Syst Charact. 2006;23:1-11.

Gómez-Carracedo A, Alvarez-Lorenzo C, Coca R, MartínezPacheco R, Concheiro A, Gómez-Amoza JL. Fractal analysis of SEM images and mercury intrusion porosimetry data for the microstructural characterization of microcrystalline cellulosebased pellets. Acta Materialia. 2009;57(1):295-303.

Goole J, Deleuze P, Vanderbist F, Amighi K. New levodopa sustained release floating minitablets coated with insoluble acrylic polymer. Eur J Pharm Biopharm. 2008;68(2):310-318.

Grassi M, Voinovich D, Moneguini M, Franceschinis E, Perissutti B, Filipovic-Grcic J. Preparation and evaluation of a melt pelletised paracetamol/ stearic acid sustained release delivery system. J Control Release. 2003;88(3):381-391.

Greb E. The hour of the particle. Pharm Technol. 2010;Jul.:3842.

Grycze A, Schminke S, Maniruzzaman M, Beck J, Douramis D. Development and evaluation of orally disintegrating tablets (ODTs) containing ibuprofen granules prepared by hot melt extrusion. Colloid Surface B. 2011;86(2):275-284.

Hamedelniel EI, Bajdik J, Pintye-Hódi K. Optimization of preparation of matrix pellets containing ethylcellulose. Chem Eng Process. 2010;49(1):120-124.

Han X, Wang L, Sun Y, Liu X, Liu W, Du Y, et al. Preparation and evaluation of sustained-release diltiazem hydrochloride pellets. Asian J Pharm Sci. 2013;8(4):244-251.

Hauptstein S, Müller C, Dünnhaupt S, Laffleur F, BernkopHauptstein S. Preactivated thiomers: Evaluation of gastroretentive minitablets. Int J Pharm. 2013;456(2):473-479.
He X. Integration of physical, chemical, mechanical and biopharmaceutical properties in solid oral dosage form development. In: Yihong Q, Chen Y, Zhang GZZ, Liu L, Porter W, editors. Developing solid oral dosage forms: pharmaceutical theory and practice. 1st ed. Burlington: Elsevier; 2009. p. 409441 .

Heckötter UM, Larsson A, Sriamornsak P, Kumpugdee-Vollrath M. Effect of annealing time and addition of lactose on release of a model substance from Eudragit ${ }^{\circledR}$ RS coated pellets produced by a fluidized bed coater. Chem Eng Res Des. 2011;89(6):697-705.

Hiorth M, Liereng L, Reinertsen R, Tho I. Formulation of bioadhesive hexylaminolevulinate pellets intended for photodynamic therapy in the treatment of cervical cancer. Int J Pharm. 2013;441(1-2):544-554.

Hung SF, Hsieh CM, Chen YC, Lin CM, Ho, HO, Sheu MT. Formulation and process optimization of multiparticulate pulsatile system delivered by osmotic pressure-activated rupturable membrane. Int J Pharm. 2015;480(1-2):15-26.

Ibrahim MA, El-Badry M. Formulation of immediate release pellets containing famotidine solid dispersions. Saudi Pharm J. 2014;22(2):149-156.

Issa MG, Pessole L, Oliveira GGG, Ferraz HG. Revestimento de paracetamol para compressão direta em equipamento de leito fluidizado utilizando-se Kollicoat SR $30 D^{\circledR}$ e Kollicoat Protect ${ }^{\circledR}$. Rev Bras Farm. 2012a;93(2):225-231.

Issa MG, Pessole L, Takahashi AI, Andreo-Filho, N, Ferraz HG. Physicochemical and dissolution profile characterization of pellets containing different binders obtained by the extrusionspheronization process. Braz J Pharm Sci. 2012b;48(3):379-388.

Jedinger N, Schrank S, Mohr S, Feichtinger A, Khinast J, Roblegg E. Alcohol dose dumping: The influence of ethanol on hot-melt extruded pellets comprising solid lipids. Eur J Pharm Biopharm. 2015;92:83-95.

Johnstone C, Pairaudeau G, Pettersson JA. Creativity, innovation and lean sigma: a controversial combination? Drug Discov Today. 2011;16(1/2):50-57.

Kalivoda A, Fischback M, Kleinebudde P. Application of mixtures of polymeric carriers for dissolution enhancement of fenofibrate using hot-melt extrusion. Int J Pharm. 2012;429(12):58-68. 
Katakam VK, Reddy S, Panakanti PK, Yamsani MR. Design and evaluation of a novel gas formation-based multiple-unit gastroretentive floating drug delivery system for quetiapine fumarate. Trop J Pharm Res. 2014;13(4):489-496.

Keen JM, Foley CJ, Hughey JR, Bennett RC, Jannin V, Rosiaux Y, et al. Continuous twin screw melt granulation of glyceryl behenate: Development of controlled release tramadol hydrochloride tablets for improved safety. Int J Pharm. 2015;487(1-2):72-80.

Kulkarni PA, Kulkarni AD, Gandhi JA, Shirolkar SV, Kasture PV. Pelletization techniques as a pharmaceutical tool in the multiparticulate drug delivery system: a review. Int J Drug Formul Res. 2010;1(1):89-118.

Lamolha MA, Serra CHR. Avaliação das propriedades de fluxo dos granulados e dissolução de comprimidos de hidroclorotiazida $50 \mathrm{mg}$ obtidos por granulação úmida. Rev Bras Cien Farm. 2007;43(3):435-446.

Lehmann K. Coating of multiparticulates using polymeric solutions - formulation and process considerations. In: GhebreSelassie I, Editor. Multiparticulate Oral Drug Delivery. 1st ed. New York: Marcel Dekker Inc.; 1994. p. 51-78.

Li Z, Xu H, Li S, Li Q, Zhang W, Ye T, et al. A novel gastrofloating multiparticulate system for dipyridamole (DIP) based on a porous and low-density matrix core: In vitro and in vivo evaluation. Int J Pharm. 2014;461(1-2):540-548.

Lin X, Chyi CW, Ruan KF, Feng Y, Heng PWS. Development of potential novel cushioning agents for the compaction of coated multi-particulates by co-processing micronized lactose with polymers. Eur J Pharm Biopharm. 2011;79(2):406-415.

Liu Q, Gong Y, Shi Y, Jiang L, Zheng C, Ge L, et al. A novel multi-unit tablet for treating circadian rhythm diseases. AAPS PharmSci. 2013;14(2):861-869.

Lopes CM, Lobo JMS, Pinto JF, Costa P. Directly compressed mini matrix tablets containing ibuprofen. Preparation and evaluation sustained release. Drug Dev Ind Pharm. 2006;32(1):95-106.

Lowell S, Shields JE, Thomas MA, Thommes M. Characterization of porous solids and powders: surface area, pore size and density. 1st ed. Dordrecht: Kluwer Academic Publisher; 2004. 347p.
Lu Y, Zhang X, Lai J, Yin Z, Wu W. Physical characterization of meloxicam- $\beta$-cyclodextrin inclusion complex pellets prepared by a fluid-bed coating method. Particuology. 2009;7(1):1-8.

Mahato, RI. Pharmaceutical dosage forms and drug delivery. 1st ed. Boca Raton: Taylor \& Francis Group; 2007. 300p.

Malode VN, Paradkar A, Devarajan PV. Controlled release floating multiparticulates of metoprolol succinate by hot melt extrusion. Int J Pharm. 2015;491(1-2):345-351.

Mangwandi C, Adams MJ, Hounslow MJ, Salman AD. An investigation of the influence of process and formulation variables on mechanical properties of high shear granules using design of experiments. Int J Pharm. 2012;427(2):328-336.

Marković S, Poljanec K, Kerc J, Horvat M. In-line NIR monitoring of key characteristics of enteric coated pellets. Eur J Pharm Biopharm. 2014;88(3):847-855.

Mašić I, Ilić I, Dreu R, Ibrić S, Parojčić J, Đurić Z. An investigation into the effects of formulation variables and process parameters on characteristics of granules obtained by in situ fluidized hot melt granulation. Int J Pharm. 2012;423(2):202212 .

Mehta AM. Formulation and characterization of pellets. In: Ghebre-Selasie I, Editor. Pharmaceutical Pelletization Technology. 1st ed. New York: Marcel Dekker, Inc.; 1989. p. 241-265.

Mehta S, De Beer T, Remon JP, Vervaet C. Effect of disintegrants on the properties of multiparticulate tablets comprising starch pellets and excipient granules. Int J Pharm. 2012;422(1-2):310317.

Nordström J, Persson AS, Lazorova L, Frenning G, Alderborn G. The degree of compression of spherical granular solids controls the evolution of microstructure and bond probability during compaction. Int J Pharm. 2013;442(1-2):3-12.

Omwancha W, Mallipeddi R, Valle BL, Neau SH. Chitosan as a pore former in coated beads for colon specific drug delivery of 5-ASA. Int J Pharm. 2013;441(1-2):343-351.

Pagariya TP, Patil SB. Development and optimization of multiparticulate drug delivery system of alfuzosin hydrochloride. Colloid Surface B. 2013;102:171-177. 
Pál S, Nagy S, Bozó T, Kocsis B, Dévay A. Technological and biopharmaceutical optimization of nystatin release from a multiparticulate based bioadhesive drug delivery system. Eur J Pharm Sci. 2013;49(2):258-264.

Patel HP, Patel JK, Patel RR. Formulation development $\&$ optimization of multiple unit particles system (MUPS) containing ramipril and hydrochlorothiazide. Int J Pharm Sci. 2010;2(1):448-456.

Patel PB, Dhake AS. Multiparticulate approach: an emerging trend in colon specific drug delivery for chronotherapy. J Appl Pharm Sci. 2011;1(5):59-63.

Patel H, Patel H, Gohel M, Tiwari S. Dissolution rate improvement of telmisartan through modified MCC pellets using 32 full factorial design. Saudi Pharm J. 2016;24(5):579587.

Peng T, Zhu C, Huang Y, Quan G, Huang L, Wu L, et al. Improvement of the stability of doxycycline hydrochloride pellet-containing tablets through a novel granulation technique and proper excipients. Powder Technol. 2015;270(Part A):221229.

Pezzini BR, Ferraz HG. Perfis de dissolução em bio-dis de péletes de cetoprofeno obtidos por extrusão-esferonização e revestimento em leito fluidizado. Lat Am J Pharm. 2007;26(4):490-498.

Pezzini BR, Silva MAS, Ferraz HG. Formas farmacêuticas sólidas orais de liberação prolongada: sistemas monolíticos e multiparticulados. Braz J Pharm Sci. 2007;43(4):491-502.

Phaechamud T, Thongpin C, Choncheewa C. Shellac WaxLutrol F127 as matrix base for hot melt extrusion. Res J Pharm Biol Chem Sci. 2012;3(1):687-694.

Podczeck F, Newton JM. Influence of the standing time of the extrudate and speed of rotation of the spheroniser plate on the properties of pellets produced by extrusion and spheronization. Adv Powder Technol. 2014;25(2):659-665.

Pund S, Joshi A, Vasu K, Nivsarkar M, Shishoo C. Multivariate optimization of formulation and process variables influencing physico-mechanical characteristics of site-specific release isoniazid pellets. Int J Pharm. 2010;388(1-2):64-72.
Qi X, Jiang Y, Zhang H, Wu Z. Tablets compressed with gastric floating pellets coated with acrylic resin for gastro retention and sustained release of famotidine: in-vitro and in-vivo study. J Pharm Pharmacol. 2015;67(4):493-500.

Rabišková M, Bautzová T, Gajdziok J, Dvořáčková K, Lamprecht A, Pellequer Y, et al. Coated chitosan pellets containing rutin intended for the treatment of inflammatory bowel disease: In vitro characteristics and in vivo evaluation. Int J Pharm. 2012;422(1-2):151-159.

Rahmanian N, Ghadiri M, Jia X, Stepanek F. Characterisation of granule structure and strength made in a high shear granulator. Powder Technol. 2009;192(2):184-194.

Rahmanian N, Naji A, Ghadiri M. Effects of process parameters on granules properties produced in a high shear granulator. Chem Eng Res Des. 2011;89(5):512-518.

Riippi M, Yliruusi J, Niskanen T, Kiesvaara J. Dependence between dissolution rate and porosity of compressed erythromycin acistrate tablets. Eur J Pharm Biopharm. 1998;46(2):169-175.

Ríos ZA, Ghaly ES. The effect of formulation excipients and thermal treatment on the release properties of lisinopril spheres and tablets. BioMed Res Int. 2015;Article ID 423615:1-5.

Roblegg E, Jäger E, Hodzic A, Koscher G, Mohr S, Zimmer A, et al. Development of sustained-release lipophilic calcium stearate pellets via hot melt extrusion. Eur J Pharm Biopharm. 2011;79(3):635-645.

Roohullah, Iqbal Z, Zada A, Nasir F, Akhlaq M, Sadozai SK, et al. Preparation and in vitro evaluation of sustained release phenytoin sodium capsules prepared by co-evaporation method using different polymers. World Appl Sci J. 2014;32(10):20632069.

Sabin G, Breitkreitz MC, Souza AM, Fonseca P, Calefe L, Moffa M, et al. Analysis of pharmaceutical pellets: An approach using near-infrared chemical imaging. Anal Chim Acta. 2011;706(1):113-119.

Sandner P, Ziegelbauer K. Product-related research: how research can contribute to successful life-cycle management. Drug Discov Today. 2008;13(9/10):457-465. 
Santos H, Veiga F, Pina M, Podczeck F, Sousa J. Physical properties of chitosan pellets produced by extrusionspheronization: influence of formulation variables. Int J Pharm. 2002;246(1-2):153-169.

Santos HMM, Veiga FJB, Pina MET, Sousa JJMS. Obtenção de pellets por extrusão e esferonização farmacêutica. Parte I. Avaliação das variáveis tecnológicas e de formulação. Braz J Pharm Sci. 2004;40(4):455-470.

Santos H, Veiga F, Pina ME, Sousa JJ. Compaction, compression and drug release properties of diclofenac sodium and ibuprofen pellets comprising xanthan gum as a sustained release agent. Int J Pharm. 2005;295(1-2):15-27.

Santos HMM, Veiga FJB, De Pina EMST, Sousa JJMS. Obtenção de pellets por extrusão e esferonização farmacêutica. Parte II. Avaliação das características físicas de pellets. Braz J Pharm Sci. 2006;42(3):309-318.

Schrank S, Kann B, Saurugger E, Hainschitz M, Windbergs M, Glasser BJ, et al. The effect of the drying temperature on the properties of wet-extruded calcium stearate pellets: pellet microstructure, drug distribution, solid state and drug dissolution. Int J Pharm. 2015;478(2):779-787.

Sharma VJ, Amin PD. Development of extended release matrices of rifampicin using hot melt extrusion technique. J Appl Pharm Sci. 2013;3(10):30-38.

Šibanc R, Kitak T, Govedarica B, Srčič S, Dreu R. Physical properties of pharmaceutical pellets. Chem Eng Sci. 2013;86:5060.

Sonaglio D, Beringhs AD, Porfírio A, Bataille B. On the factors influencing the extrusion strain, particle size and dissolution behavior of multiparticulate systems obtained by extrusion/ spheronization. Powder Technol. 2012;230:54-62.

Sousa JJ, Sousa A, Podczeck F, Newton JM. Factors influencing the physical characteristics of pellets obtained by extrusionspheronization. Int J Pharm. 2002a;232(1-2):91-106.

Sousa JJ, Sousa A, Moura MJ, Podczeck F, Newton JM. The influence of core materials and film coating on the drug release from coated pellets. Int J Pharm. 2002b;233(1-2):111-122.

Souza DF, Goebel K, Andreazza IF. Development of enteric coated sustained release minitablets containing mesalamine. Braz J Pharm Sci. 2013;49(3):529-536.
Stoltenberg I, Breitkreutz J. Orally disintegrating mini-tablets (ODMTs) - A novel solid oral dosage form for paediatric use. Eur J Pharm Biopharm. 2011;78(3):462-469.

Szkutnik-Fiedler D, Balcerkiewicz M, Sawicki W, Grabowski T, Grzeskowiak E, Mazgalski J, et al. In vitro - in vivo evaluation of a new oral dosage form of tramadol hydrochloride--controlledrelease capsules filled with coated pellets. Acta Pol Pharm. 2014;71(3):469-475.

Tissen C, Woertz K, Breitkreutz J, Kleinebudde P. Development of minitablets with $1 \mathrm{~mm}$ and $2 \mathrm{~mm}$ diameter. Int J Pharm. 2011;416(1):164-170.

Tomuta I, Leucuta SE. The influence of formulation factors on the kinetic release of metoprolol tartrate from prolong release coated minitablets. Drug Dev Ind Pharm. 2007;33(10):10701077.

Tran HTT, Park JB, Hong K, Choi H, Han H, Lee J, et al. Preparation and characterization of $\mathrm{pH}$-independent sustained release tablet containing solid dispersion granules of a poorly water-soluble drug. Int J Pharm. 2011;415(1-2):83-88.

United States Pharmacopeia. 38th ed. Rockville: United States Pharmacopeial Convention, 2015.

Vemula SK. Formulation and pharmacokinetics of colon-specific double-compression coated minitablets: Chronopharmaceutical delivery of ketorolac tromethamine. Int J Pharm. 2015;491(12):35-41.

Verhoeven E, Vervaet C, Remon JP. Xanthan gum to tailor drug release of sustained-release ethylcellulose mini-matrices prepared via hot-melt extrusion: in vitro and in vivo evaluation. Eur J Pharm Biopharm. 2006;63(3):320-330.

$\mathrm{Xu}$ M, Liew CV, Heng PWS. Evaluation of the coat quality of sustained release pellets by individual pellet dissolution methodology. Int J Pharm. 2015;478(1):318-327.

Wan LSC. Manufacture of core pellets by balling. In: GhebreSelassie I. Multiparticulate oral drug delivery. 1st ed. New York: Marcel Dekker Inc.; 1994. p. 1-15.

Wang J, Sun Y, Li B, Fan R, Li B, Yin T, et al. Preparation and evaluation of tamsulosin hydrochloride sustained-release pellets modified by two-layered membrane techniques. Asian J Pharm Sci. 2015;10(1):31-39. 
Physical characterization of multiparticulate systems

Weyenberg W, Vermeire A, Remom JP, Ludwig A. Characterization and in vivo evaluation of ocular bioadhesive minitablets compressed at different forces. J Control Release. 2003;89(2):329-340.

Weyenberg W, Bozdag S, Foreman P, Remon JP, Ludwig A. Characterization and in vivo evaluation of ocular minitablets prepared with different bioadhesive Carbopol-starch components. Eur J Pharm Biopharm. 2006;62(2):202-209.

Yeung CW, Rein H. Hot-melt extrusion of sugar-starch-pellets. Int J Pharm. 2015;493(1-2):390-403.

You C, Liang X, Sun J, Sun L, Wang Y, Fan T, et al. Blends of hydrophobic and swelling agents in the swelling layer in the preparation of delayed-release pellets of a hydrophilic drug with low MW: Physicochemical characterizations and in-vivo evaluations. Asian J Pharm Sci. 2014;9(4):199-207.
Zerbini APNA, Ferraz HG. Sistemas multiparticulados: minicomprimidos. Rev Bras Cien Farm Bas Apl. 2011;32(2):149158.

Zhang C, Xu M, Tao X, Tang J, Liu Z, Zhang Y, et al. A floating multiparticulate system for ofloxacin based on a multilayer structure: In vitro and in vivo evaluation. Int J Pharm. 2012;430(1-2):141-150.

Received for publication on $28^{\text {th }}$ November 2016 Accepted for publication on $28^{\text {th }}$ March 2017 